\title{
A new mechanism for efficient hydrocarbon electro-extraction from Botryococcus braunii
}

\author{
Alexis Guionet ${ }^{1}$, Bahareh Hosseini ${ }^{2}$, Justin Teissié ${ }^{3}$, Hidenori Akiyama ${ }^{1,2}$ and Hamid Hosseini ${ }^{1,2^{*}}$
}

\begin{abstract}
Background: Recent understanding that specific algae have high hydrocarbon production potential has attracted considerable attention. Botryococcus braunii is a microalga with an extracellular hydrocarbon matrix, which makes it an appropriate green energy source.

Results: This study focuses on extracting oil from the microalgae matrix rather than the cells, eliminating the need for an excessive electric field to create electro-permeabilization. In such a way, technical limitations due to high extraction energy and cost can be overcome. Here, nanosecond pulsed electric fields (nsPEF) with 80 ns duration and 20-65 kV/cm electric fields were applied. To understand the extraction mechanism, the structure of the algae was accurately studied under fluorescence microscope; extraction was quantified using image analysis; quality of extraction was examined by thin-layer chromatography (TLC); and the cell/matrix separation was observed real-time under a microscope during nsPEF application. Furthermore, optimization was carried out by screening values of electric fields, pulse repetition frequencies, and energy spent.
\end{abstract}

Conclusions: The results offer a novel method applicable for fast and continues hydrocarbon extraction process at low energy cost.

Keywords: Green energy, Biofuel, Hydrocarbon, Extraction, Botryococcus braunii kützing, Nanosecond pulsed electric field (nsPEF)

\section{Background}

Biodiesel from algae is a promising solution in the field of green energy. While energy derived from petroleum generates a huge carbon footprint, biodiesel generates an identical amount of carbon as is captured by the feed algae production [1]. Indeed, while growing, algae captures carbon from atmospheric $\mathrm{CO}_{2}$ for diverse metabolic activity, especially hydrocarbon formation. All carbon used for fatty acid formation comes from atmospheric $\mathrm{CO}_{2}$, one reason why biodiesel has grown increasingly important in the new field of bioenergy. Additionally, improving production efficiency will lead to lower cost. Currently, biodiesel is generally derived from plant crops,

\footnotetext{
${ }^{*}$ Correspondence: hosseini@kumamoto-u.ac.jp

1 Bioelectrics Department, Institute of Pulsed Power Science, Kumamoto

University, 2-39-1 Kurokami, Kumamoto 860-8555, Japan

Full list of author information is available at the end of the article
}

but a more promising method is by using microalgae [2, 3]. Some microalgae species are able to produce highquantity hydrocarbons which can be rendered to biogasoline. Moreover, for growing algae, arable areas are not required and production costs can be low [4]. However, regardless of whether the feedstock is microalgae or plant crops, hydrocarbon extraction requires energy.

Pulsed electric field (PEF) is anticipated as a promising method for hydrocarbon extraction from microalgae as it is able to permeabilize membranes and to weaken walls of cells [5-8]. Once permeabilized, some intracellular elements may be extracted from cells; protein, for example, can be extracted from intracellular algae using PEF [9-11]. Regarding pulse length, nanosecond pulsed electric fields (nsPEF) have been shown to be more energy efficient than millisecond or microsecond pulsed electric

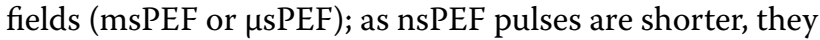


generally consume less energy even when applied voltages are higher [12].

Botryococcus braunii is a green planktonic microalga, which has the specificity to build extracellular networks of polysaccharides and hydrocarbons as colonial matrixes [13]. These both allow cells to adhere as colonies and to float on water surfaces, because hydrocarbons have lower density and are lighter than water [14]. Such matrixes contain over 99\% C33 and C34 compounds [15]. These long chain hydrocarbons can be hydrocracked to provide gasoline and fuel [16]. Between 25 and $40 \%$ of the oil contained in these matrixes can generally be extracted from dry weight [17], with up to $86 \%$ reported under optimal conditions [18]. However, oil extraction from an algae cake obtained by drying processes is mostly destructive and pricey.

Several research groups have noted the difficulty of extracting hydrocarbons from fast-growing microalgae, e.g., Chlorella vulgaris and Nannochloropsis sp. In these types of microalgae, hydrocarbons are produced inside the cell cytoplasm [19], generally requiring alternative extraction methods [20-24]. On the other hand, hydrocarbons stocked in the matrix of Botryococcus braunii have already been secreted out of cells [15], making them easier to access.

The goal of this study is to verify a novel method for fast and efficient hydrocarbon extraction from microalgae. Here, we show that hydrocarbons of Botryococcus braunii are more efficiently extractable by nsPEF. Screening various conditions allowed us to set parameters for rapid and energy-efficient extraction. Furthermore, we suggest a new continuous extraction method to allow the Botryococcus braunii culture to restart directly after oil and polysaccharides extraction. Such system is adaptable as an industrial oil and polysaccharide extraction process at low energy cost.

\section{Results nsPEF profile}

Figure 1 shows the voltage waveform of the nsPEF with a pulse duration of $80 \mathrm{~ns}$ and voltage of $12.8 \mathrm{kV}$. There was a small unwanted spike of around $12 \%$ of maximal voltage at $0.9 \mu$ s after the pulse, which, under our experimental conditions, generated an electric field near $7.5 \mathrm{kV} / \mathrm{cm}$, insufficient to have any impact on extraction.

\section{Fluorescence microscopy of Botryococcus braunii colony}

Protocol for fluorescence microscopy is described in the Additional file 1: Section 1-3). Without nsPEF application, due to pressure of the cover glass, hydrocarbons were progressively expended from colonies (Fig. 2a-c). Despite this, we could observe polysaccharides linked to basal parts of each alga cell by dichotomial ramification,

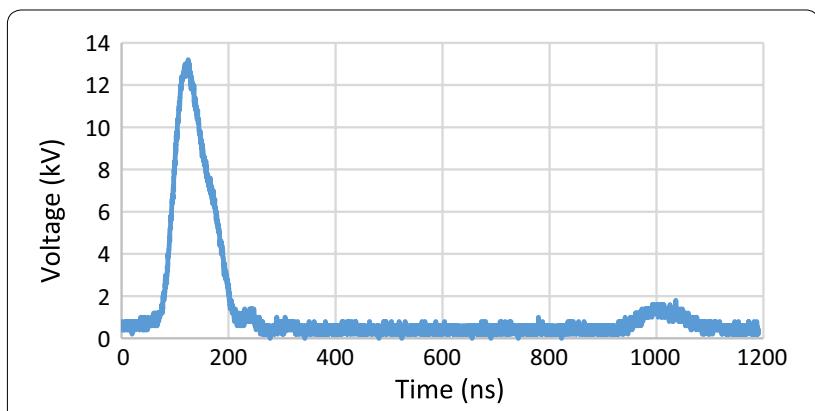

Fig. 1 Pulse profile using 10 cuvettes in parallel with main pulse and a negligible spike at $0.9 \mu \mathrm{s}$

and hydrocarbon inside the colony, with cells surrounding the surface of the colonies (Fig. 2a, c).

In Fig. 2d, cell walls colored in red, from where a ring on the upper part and a cap on basal part, produce both hydrocarbons and polysaccharides, to form the matrix. Botryococcus braunii is known to be able to form colonies with sizes up to $1 \mathrm{~mm}$, starting from a single cell by the secretion of a matrix containing hydrocarbons [25]. Our observations of colonies and of single cells suggest that the ring on the upper and the cap on the basal parts secrete the matrix from the single cell stage and continue to do so during cell division. This constitutes a kind of anchorage, allowing each cell to retain basal part inside the colony and apical part outside the colony during its development.

The observation (Fig. 2a, c) is important, as it shows that pressing the floating multicellular assembly can yield to hydrocarbon extraction. This in part may explain the nsPEF extraction, if we consider that pressure jumps are induced by each single PEF pulse [26]. While exerting pressure can facilitate a partial hydrocarbon extraction [27], after pressing, the cells are still adhered to the matrix holding considerable amount of hydrocarbons (Fig. 2b, c). This refers to additional mechanisms involved during the nsPEF application, which can promote further extraction and is subject of the next sections.

\section{Microscopic observation during nsPEF treatment}

Microalgae were submitted to trains of nsPEF and were observed real-time under a microscope using an electrode assembly (see "Methods" section, Fig. 9). Figure 3 shows selected images for a colony, performed during application of 500 pulses with $10 \mathrm{~Hz}$ repletion rate and electric field of $144 \mathrm{kV} / \mathrm{cm}$. The associated color movies taken with the microscope are shown in the "Additional file 2" (treated with nsPEFs) and "Additional file 3" (sham treated), and are described in Additional file 1: Section 2-2). 

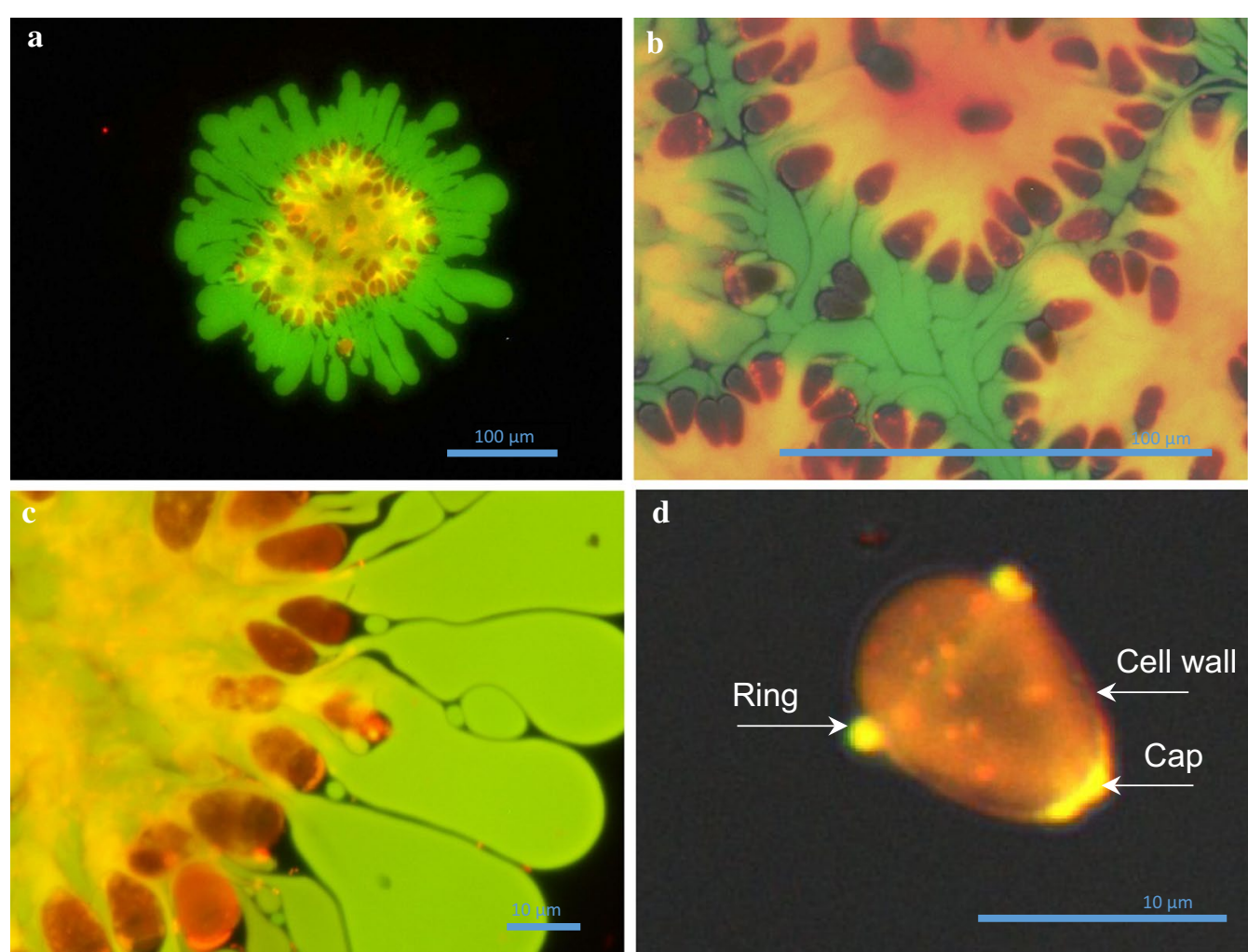

Fig. 2 Fluorescent images of hydrocarbon and polysaccharide repartition on algae colonies. a Colony full of cells (red) with polysaccharides (yellow) and hydrocarbons (green) leaving the colony $(\times 20)$; b parts of colony tightly packed together $(\times 60)$, merge of white light with filters 1 and 2; c colony full of cells $(r e d)$ with dichotomial ramification of polysaccharides (yellow) and hydrocarbons leaving the colony $(g r e e n)(\times 100)$. d Single cell, merge of white light with filters 1 and 2 ( $\times 100$ and numerically magnified)
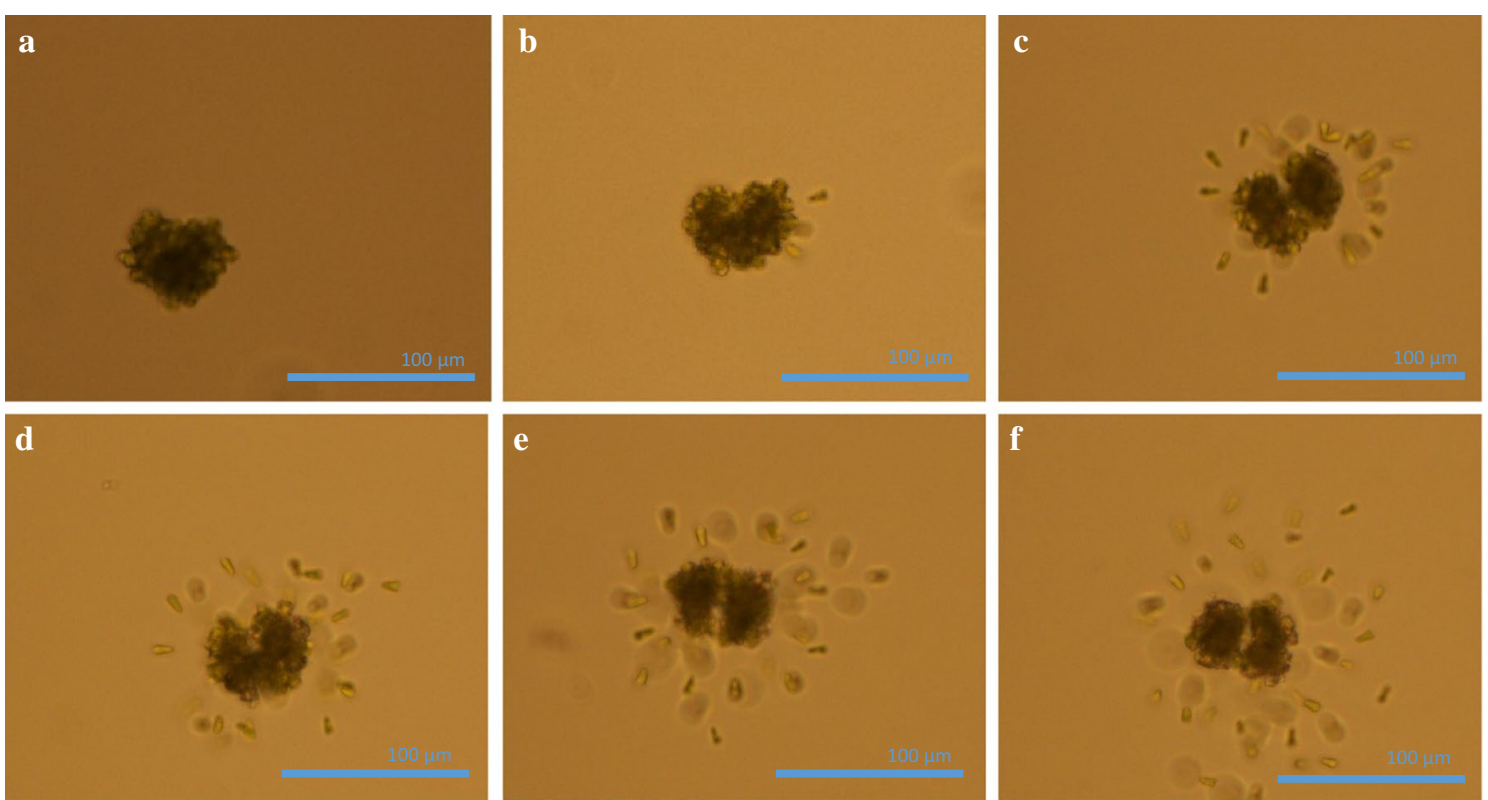

Fig. 3 Real-time microscopic observation during treatment (500 pulses, $10 \mathrm{~Hz}$, and $144 \mathrm{kV} / \mathrm{cm}$ ) (magnification × 20). a Before treatment; b after 200 pulses at $20 \mathrm{~s} ; \mathbf{c}$ after 400 pulses at $40 \mathrm{~s}$; d after $60 \mathrm{~s}$; e after $100 \mathrm{~s} ; \mathbf{f}$ after $500 \mathrm{~s}$ 
The images clearly show cells leaving the colony when PEF are applied with consequential separation from the matrix. The microscopic images are consistent with our macroscopic observations (refer to Additional file 1: Section 2-3). The phenomenon starts few seconds after treatment commences and continues for several minutes after treatment ends; its intensity depends on electric field amplitude and applied energy (for comparison of different electric fields, refer to Additional file 1: Section 2-1). This behavior of 'cell hatching,' where many cells suddenly leave their holding structure and sedimenting, is a new consequence to the already long list of biological effects of electric field pulses.

\section{Voltage effects on hydrocarbon extraction}

The dissociation effect on the multicellular assembly was clearly affecting the extracellular matrix. This was indeed confirmed by the analysis of the supernatant of pulsed floating microalgae obtained with the macroscopic approach on pulsing cuvettes (see Additional file 1: Section 2-3). Hydrocarbons were electro-extracted as shown by the fluorescence assay (see Additional file 1: Section 2-2).

To study the influence of voltage amplitude, three values of $21.5,39$, and $64 \mathrm{kV} / \mathrm{cm}$ electric fields were used. The results are summarized in Fig. 4. The spent energy for 2 cuvettes, both filled with $450 \mu$ algae, was considered. Efficiency of electro-extraction was determined using supernatant color analyses. Various frequencies (pulse repetition rates) of $1,10,100$, and $500 \mathrm{~Hz}$ were utilized. Data were compared according to energy spent, which depended on shot number and electric field (voltage).
The supernatant was confirmed using TLC to be composed of hydrocarbons, more precisely polar lipids (see Additional file 1: Section 2-4, Figure S5).

Figure 4 shows that $21.5 \mathrm{kV} / \mathrm{cm}$ electric field is not sufficient to extract hydrocarbons even with high energy expenditure. Experiments at $39 \mathrm{kV} / \mathrm{cm}$ and $64 \mathrm{kV} / \mathrm{cm}$ show approximately the same efficiency: $50 \%$ of extraction after applying approximately $25 \mathrm{~J}(27.8 \mathrm{~J} / \mathrm{ml})$ and $80 \%$ after $50 \mathrm{~J}(55.6 \mathrm{~J} / \mathrm{ml})$, while $64 \mathrm{kV} / \mathrm{cm}$ shows a higher rate of efficiency increase at lower energies. The results give evidence that there is an electric field threshold value under which extraction is not possible. The extraction efficiency is not sensitive to the total energy for energies above $50 \mathrm{~J}(55.6 \mathrm{~J} / \mathrm{ml})$. At lower energy levels, the extraction was controlled by the field strength. In Fig. 4, the results are not sensitive to pulse repetition frequency as well; for each electric field, the observations are the same for different frequencies, meaning that it is possible to use fast treatment (i.e., a high shot number applied in a short time) to extract a high amount of hydrocarbons, especially if a flow treatment process for industrial scale would be adapted $[9,10]$.

\section{Experiment with homogenous energy}

To compile comprehensive data, a series of three experiments were conducted under constant energies; the results are shown in Fig. 5. The shot numbers were chosen depending on the electric field to ensure a constant energy. All experiments were carried out at $10 \mathrm{~Hz}$ frequency.

As the thermal effect was not negligible above $35 \mathrm{kV} /$ $\mathrm{cm}$ at $300 \mathrm{~J}(333.3 \mathrm{~J} / \mathrm{ml})$ (measured temperature increase

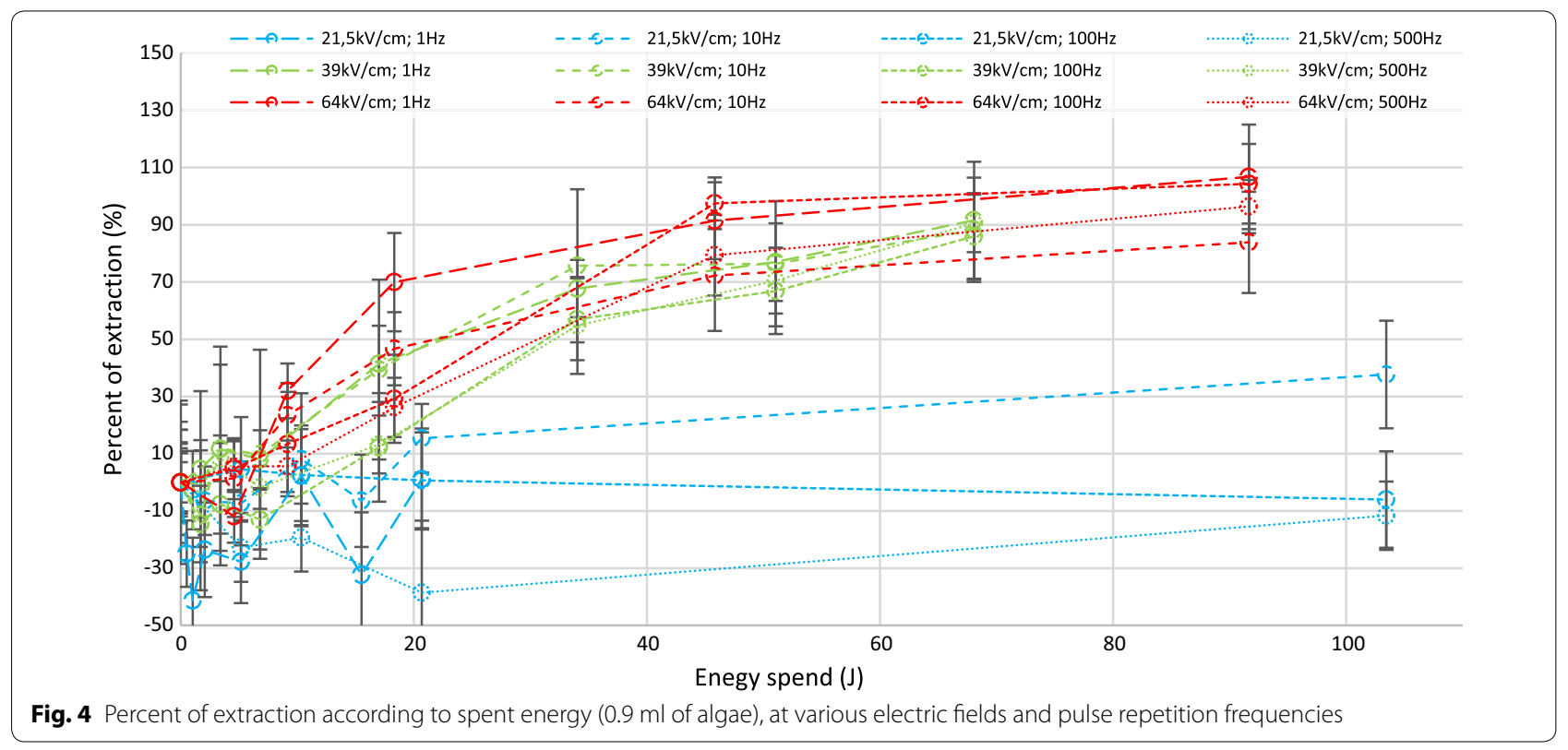




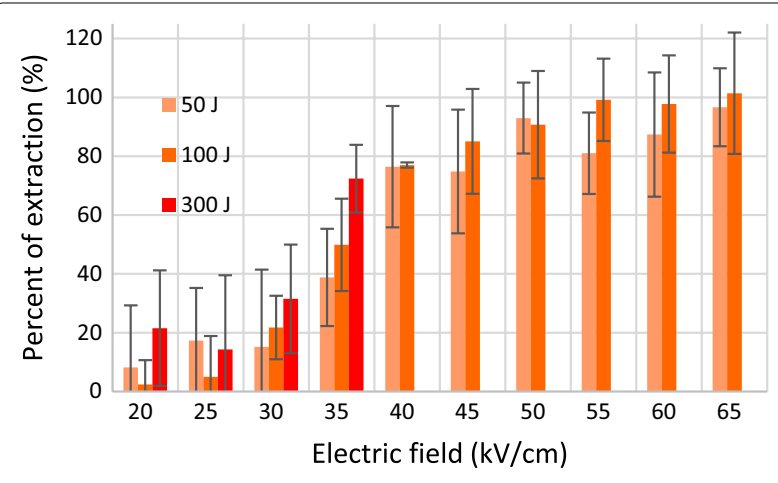

Fig. 5 Percent of hydrocarbon extraction according to electric field, at constant energy consumptions

was over $5{ }^{\circ} \mathrm{C}$ ), the experiments were not conducted under those conditions. Full extraction was reached with sufficient electric fields higher than $40 \mathrm{kV} / \mathrm{cm}$. The experiments confirm that $25 \mathrm{kV} / \mathrm{cm}$ was insufficient for hydrocarbon extraction even when a large amount of energy was spent. Consequently, augmentation of energy expenditure only displays a positive effect on the extraction when the electric filed is between 30 and $45 \mathrm{kV} / \mathrm{cm}$, though the differences are not significant.

In Fig. 5, of interest is that using two times more energy enables only $10 \%$ increase in extraction, e.g., at $45 \mathrm{kV} /$ $\mathrm{cm}, 50 \mathrm{~J}$, corresponding to 1100 shots for a duration of $110 \mathrm{~s}$, is sufficient for almost $75 \%$ extraction; while twice the energy (100 J, corresponding to 2200 shots for a duration of $220 \mathrm{~s}$ ) results in $85 \%$. Optimal conditions for oil extraction appears to be $50 \mathrm{~J}(55.6 \mathrm{~J} / \mathrm{ml})$ at $50 \mathrm{kV} / \mathrm{cm}$. Therefore, on a large-scale treatment flow system (Fig. 7), the most efficient extraction can be obtained at $50 \mathrm{kV} / \mathrm{cm}$ of electric field and $55.6 \mathrm{~J} / \mathrm{ml}$ of energy per algae volume passing through the flow system.

Hydrocarbon extraction using nsPEF is a multi-factorial phenomenon which depends on three interrelated variables: the electric field, pulse number, and energy spent; this is illustrated in a 3D graph in Fig. 6. The graph represents all experimental data of extraction percentage obtained at $10 \mathrm{~Hz}$ pulse repetition rate and was drawn by bilinear interpolation.

\section{Discussion and conclusions}

In this study, various voltages, frequencies, and pulse numbers were applied to determine the extraction efficiency based on the energy spent. We also elucidated how our extraction system functions. Combining macroscopic and microscopic observations showed, under a sufficient electric field, the matrix and cells were separated, and that matrix was composed largely of hydrocarbons.

It has been proved that electric field effect on biologic material sometime come from electrostriction [28] or

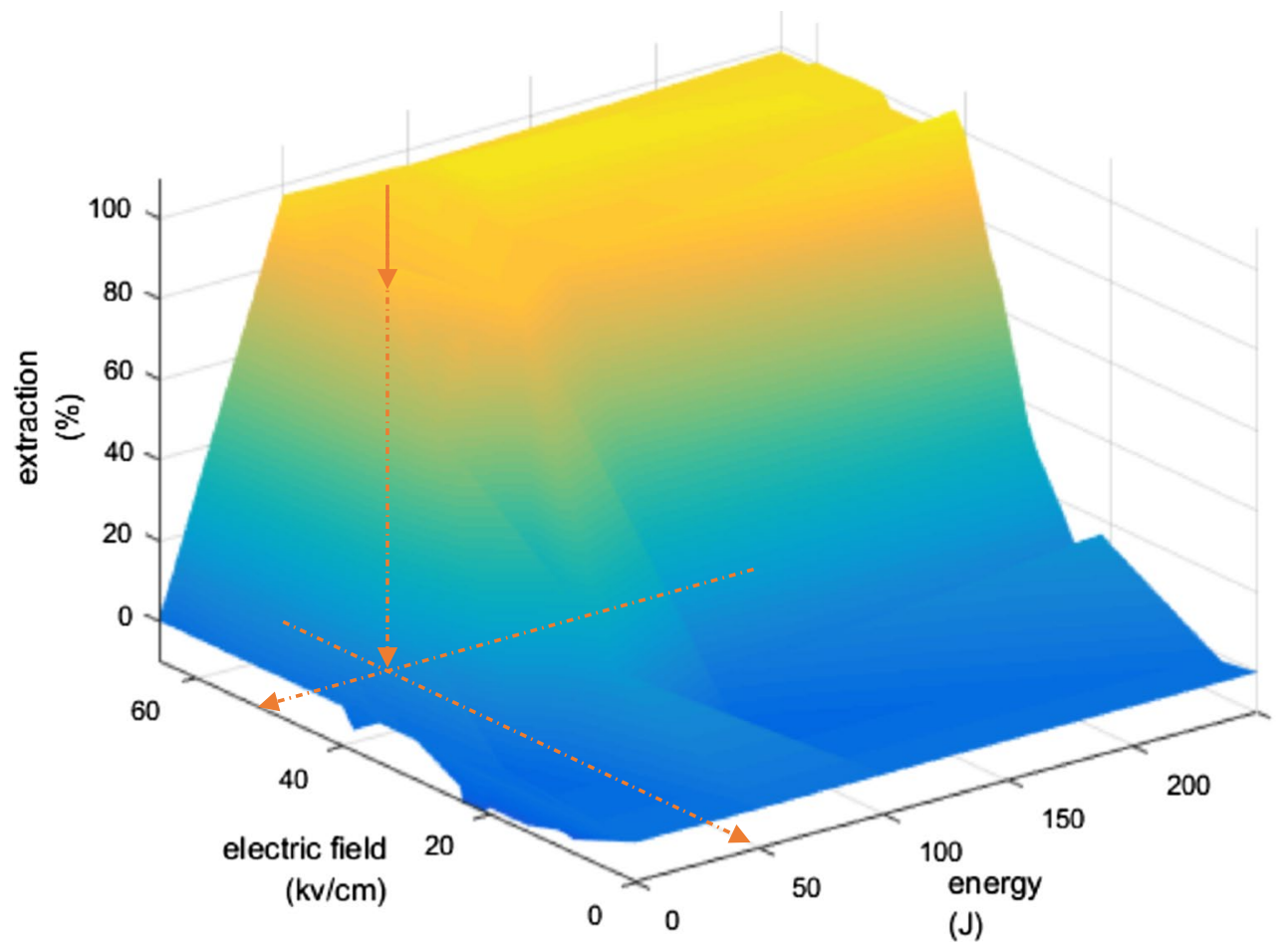

Fig. 6 Efficiency of extraction according to energy spent and the electric field. Graphic is drawn by bilinear interpolation 
pressure wave [29] induced by the potential difference generated by PEF. In this respect, two hypotheses can be formulated to explain mechanism behind the extraction: (1) The retaining wall ruptures-due to movement of charged molecules, electrostriction, or pressure waveallow cells to naturally leave the colony. (2) Polysaccharides secreted by cells and solubilized in the oily matrix are detached from cells-due to movement of charged molecules, electrostriction, or pressure wave-and having lost their anchor, cells can no longer adhere to the colony. As the retaining wall was not often observed, it is not possible to confirm the first hypothesis. Conversely, as we could see evidence of polysaccharides inside the oily matrix (Fig. 2a-c), and as detached cells leaving the colony are mostly free of oil/polysaccharides except for the cell wall (Fig. 2d; Additional file 1: Section 2-2, movies of Additional files 2,3), there is clearly a separation between cells and oil/polysaccharide of the matrix when nsPEF are applied, supporting the second hypothesis as prevailing mechanism.

Another hypothesis to explain the mechanism behind the electric field induced cell detachment can also be considered: (3) The cells in the colony might be linked together by actin filaments [30]. Exposure to nsPEF destroys actin, loosening the link between the cells, causing them to leave the colony. Indeed, in plant cells, during phragmoplasme formation, plasmodesmata are built in such a way to connect cytoplasm and actin filaments even after the end of cell division [30]. Berghöfer et al. [31] showed that nsPEF trigger actin responses in plant cells. Positive effect of PEF on actin disassembling was also shown [32]. Further investigations should focus on actin filaments observation to validate this hypothesis, as plasmodesmata might not exist for Botryococcus braunii cells and actin might be restricted into the cytoplasm.

The extraction mechanism here is completely different from electro-extraction of other microalgae species. Other unicellular algae species, which also produce a large amount of oil, do not secrete a matrix. In those cases, the electric field must destroy the plasma membrane-or at least cause poration-in order to liberate hydrocarbon vesicles, which require higher amount of electric energy. Goettel [21] showed that $1 \mathrm{MJ}$ is required to rupture cells of $1 \mathrm{~kg}$ of dry weight algae (Auxenochlorella protothecoides) from a suspension of near $100 \mathrm{~g}$ of dry weight algae per $\mathrm{kg}$ of suspension. The author also showed that the concentration of algae suspension did not affect efficiency [21]. In that case, 0.1 MJ was required to treat approximately one liter of algae suspension $(=100 \mathrm{~J} / \mathrm{ml})$. Our treatment using two electroporation cuvettes of $450 \mu \mathrm{l}(=0.9 \mathrm{ml})$ enabled extraction using $50 \mathrm{~J}(55.6 \mathrm{~J} / \mathrm{ml})$, almost with two times higher efficiency. The matrix also contains polysaccharides; therefore, the supernatant is not pure hydrocarbon and thus needs further purification. Polysaccharides hold high interest in the field of green energy as they may be used to produce bioethanol [33]; however, polysaccharides extract would be in low concentration as high percentage of the dry mass of Botryococcus braunii consists of hydrocarbons [34].

According to our screening, the best performance may be achieved at $50 \mathrm{kV} / \mathrm{cm}$, where the lowest energy consumption was needed for extraction. Higher energy spent only marginally improves extraction, and a higher electric field would not be necessary. Also shown was that frequencies from 1 to $500 \mathrm{~Hz}$ have no effect on efficiency, meaning that treatment can be rapid and thus adaptable as an industrial process.

As our method with nsPEF allows use of electric fields and energies lower than the cell irreversible membrane damage threshold [35, 36], a high portion of the algae cells may survive during the extraction. This is an important advantage; as such, it may be considered an in vivo extraction' method (Fig. 7).

Current oil extraction processes are mostly destructive; after the culture reaches a stationary state, oil is extracted from an algae cake obtained by drying [37, 38]. Conversely, our method may allow the culture to restart directly after oil and polysaccharide extraction, like chemical extraction method [39]. As such, our system is adaptable as a continuous oil and polysaccharide extraction process at low energy cost. In the flow treatment process, electric field application to treat large volumes was examined for bacterial eradication and protein extraction from microalgae $[9,10,12,40]$. In particular, it is possible to design a system using a derivation to separate algae culture from a bioreactor, treat it by

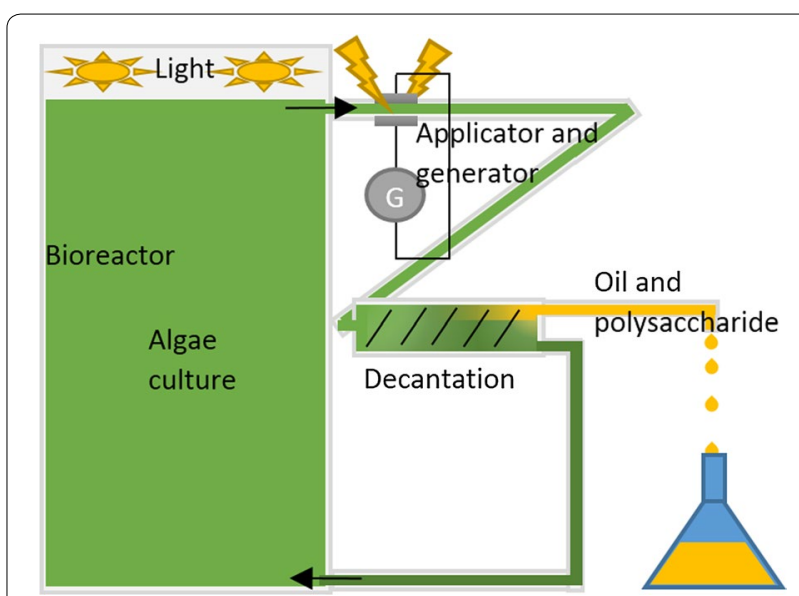

Fig. 7 Possible assembly for industrial continuous production of lipids and polysaccharides 
nsPEF, extract oil and polysaccharide by in-line decantation (lamellar decanter might help to lead single cells on the bottom part and matrix on the upper part), and then return the medium and surviving algae to the bioreactor, as shown in Fig. 7. In such a system, production of oil and polysaccharide might be faster than in a batch system, as the culture would not have to restart from zero. After treatment, cells can directly restart to grow and divide to produce more oil and polysaccharide (Fig. 7). This type of system might also minimize the initial as well as running cost, because the separation of cells and extract can be done rapidly by simple decantation, thus requiring little energy and space.

\section{Methods}

\section{Botryococcus braunii growth}

A frozen preserved strain of Botryococcus braunii Kützing race B (NIES836) from the National Institute for Environmental Studies (NIES) was used to raise the pre-culture, $30 \mathrm{ml}$ of which was incubated at $21{ }^{\circ} \mathrm{C}$ with $200 \mathrm{ml}$ of AF-6 medium under agitation (40 rpm), permanent light (photon flux density $=20 \mu \mathrm{mol} / \mathrm{m}^{2} / \mathrm{s}^{1}$ ), and air containing $2 \% \mathrm{CO}_{2}$ supply. The batch was cultivated in pre-culture and culture steps. The culture medium was changed and renewed between the pre-culture and culture steps to provide additional nutrients for the growth. The culture was grown for about 100-130 days to reach to the stationary phase. The inoculum was standardized, and the initial concentration was fixed at $10^{6}$ colonies $/ \mathrm{ml}$. Colony organizations were observed under a fluorescence microscope (Nikon, Eclipse Ti-U) using oil and polysaccharides stain (for more information, refer to Additional file 1: Section 1-3).

\section{Pulsed electric field application}

The generator used was a magnetic pulse compression (MPC) modulator [41, 42] (nsBioPEFs, Fusiontech, Japan) with $30 \Omega$ internal resistance. Eight cuvettes containing AF- 6 media $(350 \mu \mathrm{s} / \mathrm{cm})$ of $286 \Omega$ resistance and 2-mm gap electroporation (Molecular Bio-Product) were connected in parallel. Except for experiments requiring large volumes, these cuvettes were only used for impedance matching. Two cuvettes were connected in parallel (total 10 parallel cuvettes) and each filled with $450 \mu \mathrm{l}$ of the microalgae culture for experiments, as shown in Fig. 8.

Figure 9 shows a test section made for real-time observations under the microscope. The test section has a gap

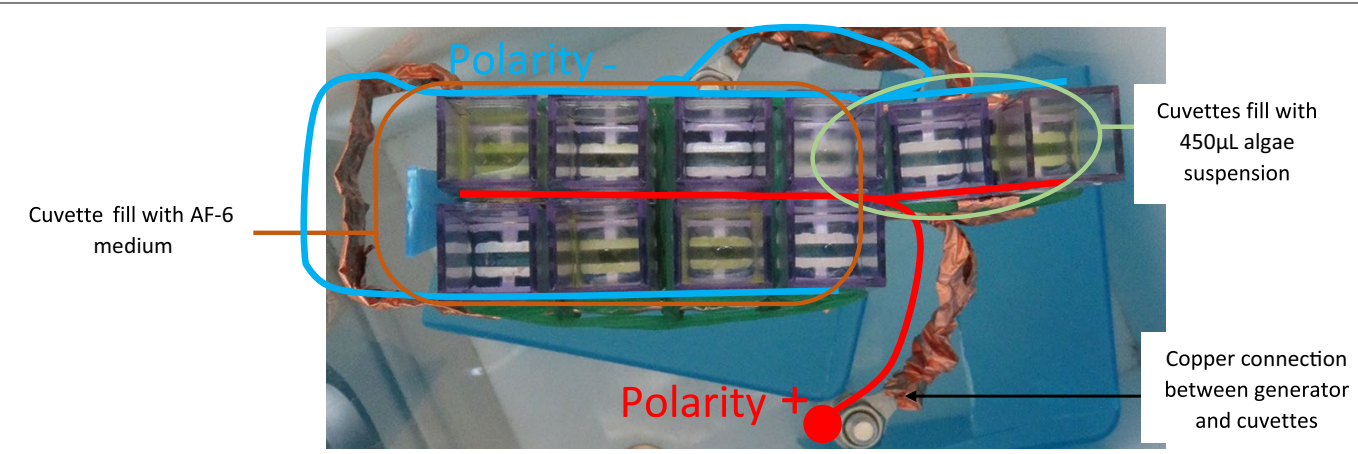

Fig. 8 Photo of connection between cuvettes under treatment with nsPEF

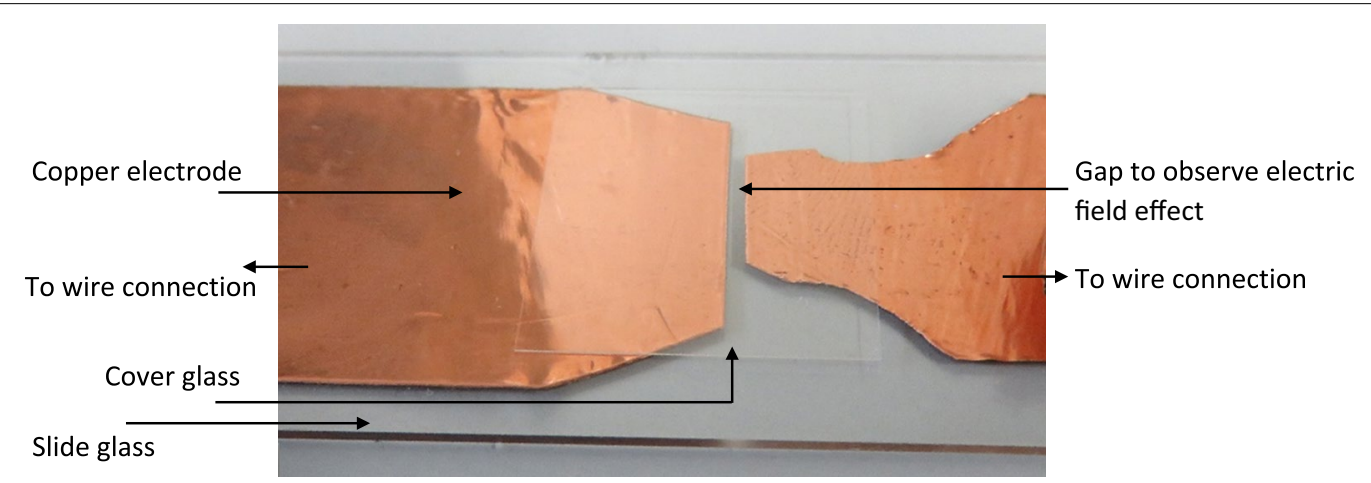

Fig. 9 The composition of the test section used to apply nsPEF under microscope 
distance of $0.9 \mathrm{~mm}$. It consists of two $0.2-\mathrm{mm}$ thickness copper plate electrodes, a slide, and a cover glass. It was connected in parallel with the cuvettes of Fig. 8; due to its high resistance, the same voltage waveform as Fig. 1 was recorded for the micro-gap.

Voltage was recorded by a Tektronix P6015A (1000×, $3.0 \mathrm{pF}, 100 \mathrm{M} \Omega$ ) voltage probe. The oscilloscope used was a Tektronix DPO-4104 digital phosphor oscilloscope. Current was recorded using the device's internal probe.

\section{Quantification of hydrocarbon extraction}

After pulse treatment, the suspension in the electroporation cuvettes was homogenized, and $880 \mu \mathrm{l}$ was taken into a micro-tube. Micro-tubes were incubated for $1 \mathrm{~h}$ at room temperature, centrifuged for $15 \mathrm{~min}$ at $2000 \mathrm{~g}$ (centrifuge separated the colonies to remain at the surface and single cells to be collected as pellet), and then photographed. For all series of experiments, photos were taken under identical light conditions and in front of a white background. Samples from each experiment series were recorded in the same photographic set. Photos were analyzed with the open source software "Image)" [43] using the plugin called RGB_profiler [44]. For each sample, red, green, and blue values of the sample supernatant were recorded, and green over red values were calculated. Color was evaluated from about 300 pixels, taken from right all the way to the left part of each sample's photograph. The cylindrical micro-tubes had lower light exposure on the left and right sides compared to the middle, causing deviations from the mean value for each sample evaluation.

Green over red value from supernatant of the control sample was used as a value of $0 \%$ of extraction, and 1 was referred to $100 \%$. According to RGB encoding, when red and green value are equal (red over green $=1$ ), it means that color of the pixel is a shade of yellow, corresponding to no green color. When supernatant was no more green, it contained no alga cell (no more presence of chlorophyll), corresponding to total extraction.

As hydrocarbons are lighter than water, they appeared as supernatants, and the quality of extraction was characterized by the color of the supernatant. Their color progressively turned from green to yellow due to separation between cells (green) and oily matrix (yellow/brown) (for details, refer to Additional file 1: Sections 2-3 and 2-5). No solvents and a low amount of algae were required, enabling a rapid screening of several conditions. To validate the evaluation, solvents were used to purify hydrocarbon of nsPEF treated samples, and those were compared with a thermally treated sample. Hydrocarbon composition was then analyzed by thin-layer chromatography (TLC) (refer to Additional file 1: Sections 1-2 and $2-4)$.

\section{Additional files}

Additional file 1. Additional materials and methods and results; includ ing Figures S1 to S7 and Table S1.

Additional file 2. Algae colony treated with $64 \mathrm{kV} / \mathrm{cm} n s P E F$.

Additional file 3. Control algae colony (sham treated).

\section{Abbreviations}

C33: lipids with chain carbon with 33 carbons; C34: lipids with chain carbon with 34 carbons; CO2: carbon dioxide; MPC: magnetic pulse compression; USPEF: microsecond pulsed electric field; msPEF: millisecond pulsed electric field; Nannochloropsis sp.: Nannochloropsis species; NIES: National Institute for Environmental Studies; nsPEF: nanosecond pulsed electric field; PEF: pulsed electric field; RGB: red green blue color model read by image; RPM: revolutions per minute; TLC: thin-layer chromatography.

\section{Authors' contributions}

$\mathrm{AG}, \mathrm{BH}, \mathrm{JT}, \mathrm{HA}$, and $\mathrm{HH}$ designed research; $\mathrm{AG}, \mathrm{BH}$, and $\mathrm{HH}$ performed research; $A G, B H, J T, H A$, and $H H$ contributed new reagents/analytic tools; $A G, B H$, and $\mathrm{HH}$ analyzed data; and $\mathrm{HH}$ and $\mathrm{AG}$ wrote the paper. All authors read and approved the final manuscript.

\section{Author details}

1 Bioelectrics Department, Institute of Pulsed Power Science, Kumamoto University, 2-39-1 Kurokami, Kumamoto 860-8555, Japan. ${ }^{2}$ Graduate School of Science and Technology, Kumamoto University, Kumamoto, Japan. ${ }^{3}$ Institute of Pharmacology and Structural Biology, University Paul Sabatier, 205 Route de Narbonne, 31077 Toulouse, France.

\section{Acknowledgements}

The authors would like to thank Mr. N. Ohnishi for his help in fluorescence microscopy.

\section{Competing interests}

The authors declare that they have no competing interests.

\section{Availability of supporting data}

All data generated or analyzed during this study are included in this published article, a supporting material "Additional file 1," and two additional movies "Additional files 2 and 3."

\section{Consent for publication}

All authors consent for publication.

Received: 24 November 2016 Accepted: 2 February 2017

Published online: 13 February 2017

\section{References}

1. Li Y, Horsman M, Wu N, Lan CQ, Dubois-Calero N. Biofuels from microalgae. Biotechnol Prog. 2008;24:815-20.

2. Chisti Y. Biodiesel from microalgae beats bioethanol. Trends Biotechnol. 2008;26:126-31.

3. Demirbaş A. Oily products from mosses and algae via pyrolysis. Energy Sourc Part Recovery Util Environ Eff. 2006;28:933-40.

4. Wijffels RH, Barbosa MJ. An outlook on microalgal biofuels. Science. 2010;329:796-9.

5. Zimmermann U, Pilwat G, Riemann F. Dielectric breakdown of cell membranes. Biophys J. 1974;14:881-99.

6. Schoenbach KH, Joshi RP, Kolb JF, Chen Nianyong, Stacey M, Blackmore PF, et al. Ultrashort electrical pulses open a new gateway into biological cells. Proc IEEE. 2004;92:1122-37.

7. Neumann E, Sowers AE, Jordan CA. Electroporation and electrofusion in cell biology. New york: Plenum; 1989. 
8. Xiao S, Guo S, Nesin V, Heller R, Schoenbach KH. Subnanosecond electric pulses cause membrane permeabilization and cell death. IEEE Trans Biomed Eng. 2011;58:1239-45.

9. Coustets M, Al-Karablieh N, Thomsen C, Teissié J. Flow process for electroextraction of total proteins from microalgae. J Membr Biol. 2013;246:751-60.

10. Coustets M, Joubert-Durigneux V, Hérault J, Schoefs B, Blanckaert V, Garnier J-P, et al. Optimization of protein electroextraction from microalgae by a flow process. Bioelectrochemistry. 2015;103:74-81.

11. Safi C, Frances C, Ursu AV, Laroche C, Pouzet C, Vaca-Garcia C, et al. Understanding the effect of cell disruption methods on the diffusion of Chlorella vulgaris proteins and pigments in the aqueous phase. Algal Res. 2015;8:61-8.

12. Guionet A, David F, Zaepffel C, Coustets M, Helmi K, Cheype C, et al. E. coli electroeradication on a closed loop circuit by using milli-, micro- and nanosecond pulsed electric fields: comparison between energy costs. Bioelectrochemistry. 2015;103:65-73.

13. Weiss TL, Roth R, Goodson C, Vitha S, Black I, Azadi P, et al. Colony organization in the green alga Botryococcus braunii (Race B) Is specified by a complex extracellular matrix. Eukaryot Cell. 2012;11:1424-40.

14. Watanabe MM, Tanabe Y. Biology and industrial potential of Botryococcus braunii. Handbook of microalgal culture: applied phycology and biotechnology. 2nd ed. Hoboken: John Wiley; 2013. p. 369-87.

15. Wolf FR, Nonomura AM, Bassham JA. Growth and branched hydrocarbon production in a strain of Botryococcus Braunii (chlorophyta). J Phycol. 1985:21:388-96.

16. Hillen LW, Pollard G, Wake LV, White N. Hydrocracking of the oils of Botryococcus braunii to transport fuels. Biotechnol Bioeng. 1982;24:193-205.

17. Wake L, Hillen L. Nature and hydrocarbon content of blooms of the alga Botryococcus braunii occuring in Australian freshwater lakes. Mar Freshw Res. 1981;32:353-67.

18. Brown AC, Knights BA, Conway E. Hydrocarbon content and its relationship to physiological state in the green alga Botryococcus braunii. Phytochemistry. 1969;8:543-7.

19. Gouveia L, Oliveira AC. Microalgae as a raw material for biofuels production. J Ind Microbiol Biotechnol. 2008;36:269-74.

20. Zbinden MDA, Sturm BSM, Nord RD, Carey WJ, Moore D, Shinogle H, et al. Pulsed electric field (PEF) as an intensification pretreatment for greener solvent lipid extraction from microalgae. Biotechnol Bioeng. 2013;110:1605-15.

21. Goettel M, Eing C, Gusbeth C, Straessner R, Frey W. Pulsed electric field assisted extraction of intracellular valuables from microalgae. Algal Res. 2013;2:401-8

22. Mercer P, Armenta RE. Developments in oil extraction from microalgae. Eur J Lipid Sci Technol. 2011;113:539-47.

23. Guderjan M, Elez-Martínez P, Knorr D. Application of pulsed electric fields at oil yield and content of functional food ingredients at the production of rapeseed oil. Innov Food Sci Emerg Technol. 2007;8:55-62.

24. Guderjan M, Töpfl S, Angersbach A, Knorr D. Impact of pulsed electric field treatment on the recovery and quality of plant oils. J Food Eng. 2005;67:281-7.

25. Demetrescu E. The chlorococcalean alga Botryococcus and its significance in hydrocarbon exploration. Geo-Eco-Mar. 1999;4:155-60.
26. Mauroy C, Portet T, Winterhalder M, Bellard E, Blache M-C, Teissié J, et al. Giant lipid vesicles under electric field pulses assessed by non invasive imaging. Bioelectrochemistry. 2012;87:253-9.

27. Lee SJ, Yoon B-D, Oh H-M. Rapid method for the determination of lipid from the green alga Botryococcus braunii. Biotechnol Tech. 1998;12:553-6.

28. Dzubiella J, Hansen J-P. Electric-field-controlled water and ion permeation of a hydrophobic nanopore. J Chem Phys. 2005;122:234706.

29. Wasungu L, Pillet F, Bellard E, Rols M-P, Teissié J. Shock waves associated with electric pulses affect cell electro-permeabilization. Bioelectrochemistry. 2014;100:36-43.

30. White RG, Barton DA. The cytoskeleton in plasmodesmata: a role in intercellular transport? J Exp Bot. 2011;62:5249-66.

31. Berghöfer T, Eing C, Flickinger B, Hohenberger P, Wegner LH, Frey W, et al. Nanosecond electric pulses trigger actin responses in plant cells. Biochem Biophys Res Commun. 2009;387:590-5.

32. Pakhomov AG, Xiao S, Pakhomova ON, Semenov I, Kuipers MA, Ibey BL. Disassembly of actin structures by nanosecond pulsed electric field is a downstream effect of cell swelling. Bioelectrochemistry. 2014;100:88-95.

33. Goh CS, Lee KT. A visionary and conceptual macroalgae-based third-generation bioethanol (TGB) biorefinery in Sabah, Malaysia as an underlay for renewable and sustainable development. Renew Sustain Energy Rev. 2010;14:842-8

34. Metzger P, Largeau C. Botryococcus braunii: a rich source for hydrocarbons and related ether lipids. Appl Microbiol Biotechnol. 2004;66:486-96.

35. Deng J, Schoenbach KH, Buescher ES, Hair PS, Fox PM, Beebe SJ. The effects of intense submicrosecond electrical pulses on cells. Biophys J. 2003;84:2709-14.

36. Gusbeth CA, Eing C, Göttel M, Frey W. Boost of algae growth by ultra short pulsed electric field treatment. Plasma Sci (ICOPS). 2013. doi:10.1109/PLASMA.2013.6633325.

37. Mata TM, Martins AA, Caetano NS. Microalgae for biodiesel production and other applications: a review. Renew Sustain Energy Rev. 2010;14:217-32.

38. Halim R, Danquah MK, Webley PA. Extraction of oil from microalgae for biodiesel production: a review. Biotechnol Adv. 2012;30:709-32.

39. Moheimani NR, Cord-Ruwisch R, Raes E, Borowitzka MA. Non-destructive oil extraction from Botryococcus braunii (Chlorophyta). J Appl Phycol. 2013;25:1653-61.

40. Guionet A. La décontamination bactérienne de l'eau par impulsions électriques ultracourtes [Internet] [phd]. Université de Toulouse, Université Toulouse III—Paul Sabatier; 2014. http://thesesups.ups-tlse.fr/2519/. Accessed 9 Oct 2015.

41. Li Z, Hosseini SHR, Ueno T, Kouno K, Tanaka F, Sakugawa T, et al. Effects of output peaking capacitor on underwater-streamer propagation. IEEE Trans Plasma Sci. 2009;37:1987-92.

42. Akiyama M, Sakugawa T, Hosseini SHR, Shiraishi E, Kiyan T, Akiyama H. High-performance pulsed-power generator controlled by FPGA. IEEE Trans Plasma Sci. 2010;38:2588-92.

43. Schneider CA, Rasband WS, Eliceiri KW. NIH image to imageJ: 25 years of image analysis. Nat Methods. 2012;9:671-5.

44. RGB_Profiler [Internet]. https://imagej.nih.gov/ij/plugins/rgb-profiler.html. Accessed 29 Sep 2016.

\section{Submit your next manuscript to BioMed Central and we will help you at every step:}

- We accept pre-submission inquiries

- Our selector tool helps you to find the most relevant journal

- We provide round the clock customer support

- Convenient online submission

- Thorough peer review

- Inclusion in PubMed and all major indexing services

- Maximum visibility for your research

Submit your manuscript at www.biomedcentral.com/submit
BioMed Central 